\title{
Ny avhandling om læremiddelbruk i svensk religionsundervisning
}

\author{
Av Geir Skeie, \\ professor i religionsdidaktikkved UiS. E-post: geir.skeie@uis.no
}

Tomas Widholm: Läromedel i praktiken. Läromedelsbruk i religionskunskap på gymnasieskolan. Linköping Studies in Pedagogical Practices. Dissertation No. 39. Linköping universitet, Linköping 2020 https://www.avhandlingar.se/ avhandling/27a4e7e16d/

Tomas Widholm ved Linköpings universitet har studert læremidler slik de er brukt i religionsundervisningens praksis på gymnaset gjennom en omfattende kvalitativ studie. Det er ikke imidlertid ikke læremidlenes innhold som er undersøkt, heller ikke elevenes bruk av de aktuelle læremidler, men måten de blir tatt i bruk på av lærerne i klasserommet. Det er med andre ord en studie av interesse for lærere og religionsdidaktikere, og ikke bare dem som forholder seg til videregående skole. Selv om utvalget på fem skoler og seks lærere kan oppfattes som beskjedent, har det blitt et omfattende materiale basert på de 93 undervisningsøktene som Widhom har fulgt. Det er derfor ikke materialets representativitet som er det sentrale, men grundigheten og detaljeringsgraden som har vært mulig takket være en imponerende konsekvens og gjennomføringsevne.

I kvalitative studier er det ofte sagt at man ikke skal bruke tall og prosenter, fordi det gir et feilaktig inntrykk av at man fanger inn et generelt bilde av hva som er typisk. I Widholms avhandling er det en hel del tall, men inntrykket er likevel ikke at han påstår noe om et generelt bilde i Sverige eller skoler i det området som er undersøkt. I stedet blir det mulig å tale informert om hva som er «mye» og «lite» av i hans datamateriale og dette er slett ikke uten interesse for didaktikere. Det er også tydelig ut fra problemstillinger, diskusjonen av tidligere forskning og teoretiske perspektiver at Widholms interesse retter seg mot lærernes undervisningspraksis, mer enn mot generell læremiddelforskning. Vi vet fra tidligere at det er mye religionsdidaktisk forskning som belyser det som skjer før og etter undervisnings- og læreprosesser, men mindre som handler om selve lærerpraksisen i klasserommet, slik det er gjort her.

Avhandlingen har et saklig og «no-nonsense»-preg der innholdsfortegnelsen ikke byr på store overraskelser for den som har lest noen avhandlinger. Widholm holder trofast på sine intensjoner og problemstillinger gjennom å fordele svarene på egne kapitler. Han spør etter hvilke læremidler som brukes; hvordan typen

1 Forfatteren var opponent ved Widholms disputas 23.10.2020 
læremiddel er koblet til innhold og arbeidsmåter, hvilke rammevilkår som har betydning og endelig hvordan læremiddelbruken kan forstås som uttrykk for lærernes religionsdidaktiske praksis.

Widholm drøfter sentrale begreper, inkludert det viktige spørsmålet om hvordan man skal definere «lremiddel» uten at viktige elementer faller utenom og uten at alt mulig blir læremidler. Selv velger han et forholdsvis bredt begrep ved å knytte an til den didaktiske trekanten: Leremidler er midler som stotter prosesser $i$ relasjonene mellom fag - elev, fag-lacer og laerer-elev, og som uttrykker eller boerer på et faginnhold som relaterer til undervisningens faginnhold. (min oversettelse fra s. 65)

Gjennom avhandlingen er det framfor alt mulig å lære en hel del om lærernes valg av læremidler, basert på deres egne utsagn i intervjuene og det bildet som tegnes ut fra forskerens omfattende observasjoner. Lærerne brukte ulike læremidler, som lærebøker, hellige tekster, artikler, leksika, film, nettsteder, men det dominerende læremiddel var det egenproduserte materialet deres, svært ofte i form av power point-presentasjoner. Widholm diskuter hvorvidt lærebøkene kan ha spilt en indirekte rolle, for eksempel som forberedelsesmateriale, men fant ikke at de var det mest dominerende læremiddel i klasseromssituasjonen, slik andre forskere har gjort. Selv om lærebøkene ikke var sentrale i lærernes presentasjoner, så spilte de en betydelig rolle i elevenes arbeid med oppgaver. Om lag halvparten av den totale undervisningstid gikk med til at elevene arbeidet med oppgaver. Den tematiske del av undersøkelsen viste at når undervisningen dreide seg om verdens religioner, var ofte læremidlene brukt til å få fokus på enkeltpersoner som kunne representere disse, gjennom besøk i skolen eller ekskursjoner eller bruk av dokumentarfilm. Også i etikkundervisning spilte film en viss rolle, men framfor alt artikler og andre tekster som skulle få fram etiske dilemmaer. I den svenske religionsundervisningen er også forholdet mellom religion og vitenskap et eget tema, og på dette punkt kom det tydeligst fram at lærerne savnet egnede læremidler.

Når det gjelder rammefaktorenes betydning for bruk av læremidler, fant ikke Widholm tydelige skiller mellom de ulike skolene, men snarere at de samme rammefaktorene gikk igjen. Alle lærerne opplevde at de hadde for liten tid, og dette er en av grunnene til at ekskursjoner ble lite brukt. Det er også et fellestrekk at skolene framstod som «ferdig digitalisert» og at dette la premisser for læremiddelbruken. Mot slutten diskuterer Widholm hvorvidt elevholdninger kan betraktes som en «rammefaktor» og peker særlig på den utbredte negative holdning som mange elever ifølge lærerne hadde til religion i alminnelighet. En annen mulig rammefaktor som drøftes er de begrensede leseferdighetene mange elever synes å ha.

Flere av resultatene i Widholms avhandling samsvarer med annen forskning som refereres, og han har valgt ut noen sentrale arbeider som får være med gjennom framstillingen som mer eller mindre faste diskusjonspartnere. Det er 
en misforståelse at all interessant forskning kommer med helt nye og uventede resultater. Det er like viktig å bekrefte og modifisere tidligere forskning. Siden det her er tale om en diskusjon med forskning både fra Skandinavia og England, peker forskningsarbeidet ut over den svenske konteksten når det gjelder religionslæreres undervisningspraksis. Det er absolutt interessant også i en norsk kontekst, og norsk forskning er med i Widholms diskusjon av sine funn. Kanskje er ikke lærernes arbeid i klasserommet så ulik på tross av de mange ulikheter som finns i organisering, læreplaner og elevsammensetning på tvers av land?

Det samlede arbeidet danner et utmerket utgangspunkt for å drøfte religionslærerrollen, didaktiske strategier, hva som er god undervisning, osv. Gjennom sin teoretiske forankring av et bredt læremiddelbegrep og gjennom å trekke inn sentrale fagdidaktiske begreper i det analytiske arbeidet gjør Widholm avhandlingen sin relevant for en bredere religionsdidaktisk diskusjon. Ut fra hans arbeid kan man gå videre til nye problemstillinger. Jeg finner det særlig interessant at han dokumenterer hvor stor plass læreres egenproduserte materiale tar i klasserommet. Tross Widholms forbehold om begrensninger ved datamaterialet, betyr dette at det ikke uten videre er riktig at læreboka alltid dominerer. Dette peker videre mot nye forskningsspørsmål, for eksempel: Hva er det som kjennetegner innholdet $\mathrm{i}$ læreres egenproduserte materiale når det gjelder slikt som religionsbegrepet og representasjon av religioner? Hvordan mottar elevene læremiddelbruken og hvilken effekt har den på deres læreprosesser og læringsutbytte? Widholms avhandling har brakt læremiddelforskning i religionsdidaktikken et stort skritt framover og kan forhåpentlig inspirere til studier i Norge. 